\title{
Pamięć Wtoch Wojciecha Karpińskiego w perspektywie teorii neuroestetycznej Semira Zekiego
}

Michał Anioł Buonarroti w liście do Aliottiego w 1542 roku napisał: „Maluje się mózgiem, nie rękami” [Michał Aniol, cyt. za Tatarkiewicz 1967: 171 $]^{1}$. Ręka podlega w procesie tworzenia rzeźby lub obrazu „mózgowi” i oku, pozostając tym samym „posłuszną umysłowi”, stanowiącemu zresztą najważniejszą władzę u artysty, gdyż to w umyśle (utożsamianym przez Buonarrotiego z wyobraźnią) powstaje idea będąca podmiotem artystycznej czynności, a czynność ta jest jej realizacją. W kolejnym fragmencie listu włoski artysta podkreśla znaczenie oka, które jest narzędziem konkretnego poznania, czyli „fundamentu” sztuki [Ligocki 1973: 165]. Jednym z pierwszych, który zainteresował się możliwościami badania percepcji wizualnej i jej związków ze sztuką, był brytyjski neurobiolog Semir Zeki. Na określenie nowych badań zaproponował termin

1 Warto wskazać teksty na temat koncepcji sztuki Michała Anioła: biografie pióra Ascania Condiviego (1553) i Giorgia Vasariego (1550, druga edycja 1568), sonety (datowane na lata 1530-1554), listy z lat 1542, 1544, 1555 i 1560, ankieta Benedetta Varchiego z 1546 oraz pochodzące z 1538 roku Dialogi o malarstwie Francesco da Hollandy z Portugalii [por. Białostocki 1966: 14; Tatarkiewicz 1967: 171; Ligocki 1973: 164; Wallis 1975; Bull 2002: 404]. 
neuroestetyka. Zeki bada procesy percepcji wizualnej w mózgu, a także w jaki sposób te procesy przekładają się na doznania estetyczne człowieka. Dotyczy to zarówno mimowolnej reakcji neurologicznej na określone bodźce wizualne, jak i tego, w jaki sposób dokonujemy sądu, czy coś jest lub nie jest estetycznie zadowalające. Brytyjski uczony zajmuje się - poza bardzo podstawowymi zagadnieniami związanymi z funkcjonowaniem obszarów mózgu odpowiedzialnych za widzenie - przeprowadzaną z perspektywy neurologicznej analizą dzieł z zakresu malarstwa, rzeźby, a także muzyki i literatury. Wynikiem jego zainteresowań jest szereg opublikowanych książek oraz artykułów naukowych - przypomnę choćby Blaski i cienie pracy mózgu. O miłości, sztuce i pogoni za szczęściem, w której opisuje neurobiologiczne podstawy percepcji estetycznej. We wstępie do książki pisze:

Sztukę, miłość i piękno uważa się powszechnie za pojęcia abstrakcyjne, choć coraz więcej przemawia za tym, że nasze przeżycia w tych obszarach są bezpośrednio skorelowane z aktywnością wyspecjalizowanych części mózgu. [...] Istnieje zatem ścisły związek między zwykłą percepcją z jednej strony a sztuką, pięknem, miłością i twórczością z drugiej. [Zeki 2012: 18]

Z kolei w pracy Inner Vision autor porusza problematykę wieloznaczności interpretacyjnej, odwołując się do badań neurologicznych i analizy dzieł, w tym między innymi przywołanego już przeze mnie Michała Anioła. Zeki określa artystów jako neurologów „badających umysł, a przez to i mózg” [Zeki 2009: 61]. Uczony w swoich pracach zajmuje się przede wszystkim widzeniem. Zauważa, że struktura kory wzrokowej odzwierciedla rodzaj informacji docierającej do niej od oka, a mózg selekcjonuje to, co jest konieczne dla otrzymania informacji o świecie widzialnym, i porównuje tę informację z tym, co już wcześniej zgromadził.

Mózg i sztuka to sposoby poznawania świata, a podróż, wędrowanie czy zwiedzanie innych krajów stanowi znów inspirację dla artystów w kreowaniu literackich światów: 
Tak, tym właśnie jest Wenecja - życiodajnym snem, pobudzeniem ducha i umysłu, wyostrzeniem wrażliwości. Jak jednak wyrazić ten sen, jak uratować Wenecję wewnątrz siebie, utrwalić jej oddziaływanie? [...] Zdarza się, że nie widzące oczy prześlizgują się po najsłynniejszych obrazach, że piękno zewnętrzne, wewnętrzna wiedza zostają uruchomione, rozłączone. Zaślepienie zdarzyć się może każdemu. Podróże powinny być właśnie przemyciem oczu, odnowieniem wrażliwości. [Karpiński 2002: 18]

Wojciech Karpiński, autor powyższych słów, zaczerpniętych z książki Pamięć Włoch, wpisuje się w istotę neoplatońskiego dziedzictwa - piękno widzialne odsyła do tego niewidzialnego, duchowego. Piękno widzialne świadczy o pięknie wyższym, objawia je i pragnie każdego człowieka do niego doprowadzić. Autor Twarzy domaga się kultury, która umożliwia człowiekowi dostrzeganie złożoności świata i ludzkiej egzystencji oraz zaspakaja potrzebę doświadczania piękna. Pamięć Włoch jest egzemplifikacją dzieła w ruchu. Pisarz ukazuje świat w ciągłej artykulacji i nieustannym odkrywaniu nowych aspektów Absolutu. Potwierdzeniem tej koncepcji są słowa Zekiego:

Uważam, że twórczość motywowana jest poszukiwaniem doskonałości i ciągłym poczuciem niedosytu. Artyści chcą dotrzeć do ponadczasowych idealnych pojęć, o których pisał choćby Platon. Ludzkie ideały nie są jednak tak stałe jak Platońskie idee, ale podlegają nieustannej ewolucji, związanej z przeżyciami, emocjami oraz nową wiedzą. [Zeki 2009: 10]

Allan Paivio dowodził, że umysł koduje docierające do niego informacje nie tylko za pomocą logogenów, ale również za pomocą imagenów (obrazów). Wyobraźnia artysty nie jest epifenomenem propozycjonalnej reprezentacji zjawisk wizualnych, ale procesem autonomicznym o identyfikowanej lokalizacji mózgowej, związanej z przetwarzaniem sensorycznym [Paivio 1991].

Sztuka jest więc swojego rodzaju eksploracją naszego aparatu poznawczego. Do tej pory przeżycia estetyczne były rozpatry- 
wane tylko od wewnątrz. Dzisiejszy stan badań neuroestetycznych pozwala nam analizować wytwory artystyczne z perspektywy mechanizmów percepcyjno-afektywnopoznawczych, stanowiących metapoziom w stosunku do wewnętrznego punktu widzenia [Duch 2003: 133-154]. Zjawiska fizyczne są niezbędne do powstania zjawisk umysłowych, ale nie wyjaśniają ich w pełni. Warto wymienić pewne „reguły” sztuki pomagające zrozumieć, dlaczego pewne wytwory artystyczne są dla nas piękne, a inne nie. Vilayanur Ramachandran przedstawia kilka zasad, które rządzą percepcją sztuki i pozwalają prześledzić reakcje układu percepcyjnego odbiorcy na bodziec w postaci dzieła artystycznego. Najważniejsza z reguł nosi nazwę „przesunięcia szczytowego” i polega między innymi na podkreśleniu niektórych elementów i pomijaniu innych, co wynika z zasady „wzmacniania różnic”; oddzielaniu pojedynczych modów wzrokowych (kształt, kolor, kinestetyka), sprzyjającym większemu skupieniu uwagi; grupowaniu percepcyjnemu pozwalającemu na segmentację obiektów od tła i dostrzeżenie abstrakcyjnych relacji podobieństwa; wzmacnianiu wrażenia przez kontrast, linię, rysunek, kolor; unikaniu nienaturalnych punktów widzenia i przypadkowych koincydencji konturów; zaskakującym grupowaniu, wywołującym zwiększone zainteresowanie; zastosowaniu aluzji i metafor silnie pobudzających korę skojarzeniową i złożone procesy myślenia; użyciu symetrii wzmagającej synchronizację pomiędzy procesami w obu półkulach mózgu, prowadzącej do silniejszego pobudzenia [Ramachandran 2003: 46-69]. Amerykański neurolog w swoich badaniach dowodzi, że istnieje też wiele przestrzeni, w których wykorzystuje się „efekt przesunięcia szczytowego”. Przykładem takiej przestrzeni jest wspomniana Italia.

W literaturze europejskiej można znaleźć liczne relacje z podróży do Włoch, tamtejsza architektura, malownicze ruiny oraz pejzaże od wieków przyciągały i przyciągają twórców, w tym romantyków i mistycznych symbolistów. W xx wieku tradycja odbywania wycieczek do Włoch w poszukiwaniu intelektualnego i duchowego piękna nie zamarła. Warto przypomnieć rosyjskiego prozaika, krytyka oraz historyka sztuki Pawła Muratowa i jego dwutomowy zbiór szkiców podróżniczych, wydany w Polsce 
pod tytułem Obrazy Włoch. Natomiast wśród polskich twórców, którzy odwiedzili Italię, należy wymienić Jarosława Iwaszkiewicza, Gustawa Herlinga-Grudzińskiego czy Zbigniewa Herberta. Karpiński w Pamięci Włoch podąża śladami wspomnianych wyżej wielkich literackich poprzedników. Jego refleksje, spostrzeżenia i uwagi pozwalają nam spojrzeć na zabytki kultury i odwiedzane miejsca także jego oczami. Jak zastanawia się narrator: „Chwilowa przyjemność oczu nie zawsze wystarcza [...]. Jak utrwalić chwilę triumfu, uaktualnić pamięć, wzbogacić wrażliwość o wymiar trwania?” [Karpiński 2002: 19]. Różne rodzaje sztuki aktywizują odrębne szlaki przetwarzania informacji czuciowej. W przypadku malarstwa - percepcji portretów, martwych natur i pejzaży - pobudzane są między innymi odmienne, specyficzne obszary kory: zakręt potyliczno-skroniowy przyśrodkowy, zakręt wrzecionowaty i zakręt boczny. Warto zwrócić uwagę na taki opis narratora:

Czasem na Canal Grande przez chwilę oślepi nas poblask słońca odbitego od fal i rzuci nowe światło na mijane pałace, czasem tchnienie wiatru, szmer wody skupi całą uwagę, ale gry natury są tu dlatego tak istotne, że dzieją się wśród wspaniałych budowli, a te są z kolei nierozłączną częścią mechanizmu, jakim jest - było - to miasto. [Karpiński 2002: 7]

Takie obrazy przestrzeni aktywizują u bohatera pole v5 związane z percepcją i ruchem²:

Informacja wizualna z siatkówki dociera do obszaru v1 w korze potylicznej. W v1 powstaje pierwotny szkic widzianego obrazu. Po przejściu vı informacja wzrokowa rozdziela się na dwa strumienie. Na strumień grzbietowy typu „gdzie?” i strumień brzuszny typu „co?”. Obszary v2, v3, v4, v5 stanowią strategiczne etapy przetwarzania wzrokowego. Przykładowo v4 odpowiada za percepcję koloru, a v5 za percepcję ruchu i położenia przestrzennego. W przetwarzaniu informacji wizualnej ważną rolę odgrywają takie części mózgu jak kora ciemieniowa (rozpoznaje własności przestrzenne, wielkość, orientację), kora skroniowa (rozpoznaje własności obiektu, kształt, barwę, teksturę), kora potyliczna z buforem wzrokowym i oknem uwagi (rozpoznaje detekcję linii, krawędzi, wyróżnia obszary) [zob. Kosslyn 2005: 333-347]. 
Wybrałem się na Torcello, aby obejrzeć katedrę i słynne mozaiki. Nie to było najciekawsze - widziałem już mozaiki piękniejsze. Ale rozgrzana słońcem cisza wysepki, powietrze przesiąknięte zapachem trawy i ziemi, czas płynący wolniej i spokojniej, uczucie spełnienia i wyzwolenia - to był znów sen na jawie, jeszcze jeden wenecki sen. Momenty uładzenia pozwalają podjąć wyzwanie, jakim jest dorobek Wenecji. [Karpiński 2002: 20]

Obrazy malarskie sklasyfikowane jako piękne aktywizują korę oczodołową i przednią część zakrętu obręczy - czyli obszary aktywne podczas wydawania sądów wartościujących, będące fragmentami „układu nagrody” [Kawabata, Zeki 2004: 1699-1705]. Tym samym obrazy uznane przez bohatera za brzydkie nie wywołują pobudzenia odmiennych obszarów anatomicznych, a jedynie powodują różnice w aktywności kory oczodołowej. Interesujące jest to, że obrazy sklasyfikowane przez bohatera jako piękne lub brzydkie wywoływały również pobudzenie kory motorycznej, różniące się jednak intensywnością:

Jeżeli miałbym wybierać malarza, który jest dla mnie symbolem Wenecji, wcieleniem jej uroku i jej skrajności, wówczas bez wahania powiedziałbym: Tintorreto. $Z$ trudem potrafilem sobie choć w przybliżeniu wyjaśnić swój stosunek do jego malarstwa, który zmieniał się od podziwu do bezradności, znużenia i znów podziwu - a stanowił spotęgowanie i trochę zdeformowane odbicie mojego stosunku do Wenecji, do tajemnych źródeł jej oddziaływania. [Karpiński 2002: 21]

Artystycznie spreparowany bodziec musi skłonić widza do zwrócenia uwagi tylko na niektóre cechy obrazowanego przedmiotu, na przykład na kolor lub kształt twarzy, nasycenie nieba barwą lub na różnice w luminancji sąsiadujących ze sobą fragmentów powierzchni obrazu. Dzięki temu bohater może skupić się tylko na tych informacjach, które zostały przez artystę szczególnie zaakcentowane na obrazie: 
Ze wszystkich obrazów Wenecji Assunta Tycjana działa chyba najsilniej. Panuje nad całym kościołem. Zawieszona bez ramy, plynie w powietrzu. Otoczona bijącym z okien kręgiem świetlnym, sama uderza najpierw wewnętrzną światłością, później różnorodną czerwienią (czerwienią sukni Marii i dwóch apostołów), wreszcie doskonałą harmonią troiście koncentrycznego ruchu: apostołów kłębiących się w dole, płynącej ku górze Madonny o szacie rozwianej, lecz o twarzy doskonale spokojnej, i Boga, będącego ruchem w bezruchu, pierwszą przyczyną i sensem całego wydarzenia. [Karpiński 2012: 21]

Podczas oglądania obrazu w mózgu bohatera intensywnie pracują przede wszystkim dwa szlaki - „co” i „gdzie”. Szlak „co” zajmuje się analizą koloru, szczególów oraz obiektów położonych w centrum pola widzenia, natomiast „gdzie” przetwarza informacje na temat poziomów jasności (luminancji), ułożenia przestrzennego namalowanych przedmiotów, jest także czuły na to, co dzieje się na peryferiach obszaru widzenia. Podczas oglądania obrazu do mózgu bohatera docierają równolegle odmienne informacje o różnych aspektach dzieła, na przykład kolor kontra luminancja, dane z centrum pola widzenia kontra informacje z peryferii. W ten sposób do świadomości przedostają się niespójne i sprzeczne dane, które mogą przyczyniać się do powstania iluzji migoczącego słońca. To potwierdza tezę, że dzieło sztuki jest bodźcem wieloznacznym. Teoretycy oraz historycy sztuki, podobnie jak sami artyści, zwracali już wcześniej wielokrotnie uwagę na niejednoznaczność i wielowątkowość przekazu artystycznego, ale tym razem stwierdzenie to zyskało neurobiologiczne uzasadnienie. Neuroestetycy liczą, że dzięki badaniom nad mózgiem estetycznym lepiej zrozumiemy, w jaki sposób człowiek radzi sobie z wieloznacznym komunikatem. Według Zekiego mózg człowieka w wyniku presji selekcyjnej jest w stanie przetwarzać trzy rodzaje informacji: jednoznaczną, dwuznaczną oraz wieloznaczną, gdzie w tej ostatniej występuje bardzo wiele równie prawdopodobnych interpretacji bodźca. Neurobiologiczna definicja wieloznaczności okazuje się inna niż definicje słownikowe: „[...] wieloznaczność to nie jest niepew- 
ność, ale pewność - pewność wielu, równie prawdopodobnych interpretacji, z których każda jest niezależna, kiedy pojawia się na scenie świadomości” [Zeki 2009: 424]. Dlatego system wzrokowy bohatera, który napotyka bodziec w postaci dzieła sztuki, musi wyjść poza standardowy odbiór i poddać je intensywnej percepcyjnej interpretacji. Staje się to widoczne, gdy bohater odwiedza sieneńską katedrę czy Libreria Piccolomini i wchodzi na terytorium, które nazwać można czymś w rodzaju bramy, oferuje ono bowiem nieoczekiwane przejście ku inaczej zorganizowanej przestrzeni, ku odmiennym jakościom i wartościom:

Wnętrze sieneńskiej katedry narzuca jednolitą atmosferę, z miejsca obejmuje władanie. Z wąskich okien spływają ukośne filary pylistego blasku, przyćmione światło delikatnie modeluje grę pasiastych kolumn i sklepień, hieroglify marmurowej posadzki powoli ożywiają w cienistych smugach. Dlatego wejście do Libreria Piccolomini stanowi zaskoczenie. Znów jednolity nastrój, lecz jakże inny. Inny świat, inna przestrzeń, inne kolory. [Karpiński 2002: 93] $]^{3}$

Przywołana przestrzeń sieneńska wyzwala ogromne emocje $\mathrm{u}$ bohatera. Pierwsze zetknięcie z ekspresją dzieła następuje na poziomie ciała, to wskazuje na pierwotne współbycie człowieka w świecie. Jak pisze Maurice Merleau-Ponty: „Świadomość jest byciem ku rzeczy za pośrednictwem ciała” [Merleau-Ponty 1945: 160-161]. Ta pierwotna intencjonalność zadomawia go w świecie przedmiotów. Postać Karpińskiego podkreśla:

3 Podobne wrażenia z odwiedzin w Sienie miał Muratow: „[... ] przypomnienie Sieny pozostaje jednym z najjaśniejszych i najbliższych sercu. $Z$ dala od Włoch obraz tego najszlachetniejszego z miast toskańskich sprawia, że nasza myśl zwraca się ku dawnym szczęśliwym podróżom. Skupia się w nim wszystko, co na dźwięk wyrazu: Włochy - przyspiesza bicie naszego serca - święte piękno antyku, kwitnąca sztuka, mowa Dantego w ustach ludu, uczucie wypełnionej powietrzem rozległej przestrzeni, tchnąca delikatną mocą ziemia, która od wieków rodzi oliwki, symbol pokoju i winogrona, symbol upojnej wesołości. W Sienie wszystko zespoliło się z jedynymi w swoim rodzaju ładem i harmonią" [Muratow 1988: 232]. 
Wszędzie jasność, śmiałość barw. Blask bije nie tylko z szerokiego okna, lecz także z malowideł ściennych, z arabeski na suficie, z oszklonych pulpitów bibliotecznych. Zanim zdołałem wyróżnić poszczególne elementy sali, widziałem mnogość kolorów i prostą geometryczność wnętrza. A jednak głównym źródłem intensywnej świetlistości jest ciągnące się wzdłuż ścian pasmo fresków. [Karpiński 2002: 93]

Na tym przedrefleksyjnym etapie następuje wywołanie relacji emocjonalnej. Ciało bohatera odczuwa związek z obiektem estetycznym. Zasadnicze elementy tej sytuacji to wytrącenie bohatera $\mathrm{z}$ praxis oraz otwarcie przestrzeni dla swobodnej gry:

Dopiero później konkretne sceny nabierają sensu, stają się ilustracją już nie mitycznie ujętej przeszłości, już nie szeregiem zastygłych od lat żywych obrazów na tematy renesansowe, lecz doskonałym - choć nie zawsze do końca szczerym - wizerunkiem konkretnej epoki, portretem konkretnych osobistości. [Karpiński 2002: 94]

Zachodzi zmiana, przejście z percepcji praktycznej na percepcję współbrzmiącą, co widać na przykładzie fragmentu opisującego przebywanie bohatera w Urbino. Jego ciało odnajduje związek z naturą:

Krajobraz górzysty, odmienny od bliskiej Umbrii: bardziej pofałdowany, ale też bardziej surowy. Łatwiej pogrążyć się w pomocną przy zwiedzaniu iluzję odkrywcy, wydobyć z szablonów, uzyskać świeżość spojrzenia. [Karpiński 2002: 131]

Nie istnieje sztuka bez chociażby najmniejszego związku z naturą. Ważna jest relacja piękno-natura. Już Buonarroti uważał, że nie ma żadnego antagonizmu między tymi realnościami, i wskazywał na konieczność „wszczepiania” przez twórcę w sztukę tego, co w naturze piękne i godne naśladowania. Pisał: „Dłutem, farbą dokonałeś sztuki równej naturze, a ręka twa ją jeszcze przewyższyła, czyniąc nam jej piękno jeszcze piękniejszym” [Michał Anioł, cyt. za Tatar- 
kiewicz 1967: 177]. Natomiast zabieganie artysty o osiągnięcie owej doskonałości już samo w sobie stanowi cnotę. Jednak w procesie twórczym nie może on ograniczać się tylko do mimetyzmu, powinien skorzystać nie tylko z „dostarczonego” przez naturę modelu, ale i ze znajdującej się w jego wyobraźni idei. O tym, czy sztuka jest „dobra” czy „zła”, a więc o jej doskonałości bądź niedoskonałości, decyduje zwłaszcza umysł („mózg”), a następnie oko i ręka. Zeki dzieli piękno na dwa typy: biologiczne - na przykład piękno twarzy albo krajobrazu - oraz sztuczne, czyli wytwory człowieka. W mózgu mamy coś w rodzaju wzorca piękna. Jeśli świat jest symptomem, to $\mathrm{z}$ jakim ukrytym procesem mamy do czynienia? Odpowiedź brzmi następująco: jest nim głębia i jej doświadczenie, lecz nie oznacza ona jedynie, że to, na co spoglądam, rozpościera się gdzieś, gdzie nie sięga mój wzrok. Bohater ma pewne zdolności, dane a priori, nie zatrzymuje się na ekscytacji, ale kieruje się ku percepcji właściwej. Następuje przejście od reprezentacji świata do świadomego uchwycenia treści dzieła: „Stałem przed idealnie spokojną wizją Biczowania i czułem, że malarstwo otwiera mi tym dziełem nowe obszary" [Karpiński 2002: 133]. Ta skomplikowana sytuacja to wynik dialektycznego charakteru przeżycia estetycznego. W deskrypcji przeżycia estetycznego ważne okazuje się uchwycenie momentów aktywności i pasywności, a co za tym idzie - zbadanie zależności i związków między czynnikiem emocjonalnym a racjonalnym. W trakcie reprezentacji podmiot uczestniczy w dialektyce spektaklu, jest widzem, to znaczy odczuwa dystans i komfort obserwatora, a zarazem aktorem, czyli tym, który na sobie doświadcza wyrażanych form życia: „Słychać ciszę zbliżającego się uderzenia” [Karpiński 2002: 133]. Percepcja estetyczna nie penetruje wyglądów, nie jest analityczna, gdyż wówczas ustanawiałaby sens rzeczy, nie zaś dzieła sztuki. Mamy w tym przypadku do czynienia głównie z aktywnością komórek nerwowych w obszarze v2 w korze potylicznej. Zawierające precyzyjne odwzorowanie topografii siatkówki neurony v1 posiadają małe pole percepcyjne i wiernie odwzorowują jedynie realne kontury. Dopiero obdarzone większymi polami recepcyjnymi komórki w obszarze v2 potrafią analizować pochodzące z V1 informacje i wnioskować o istnieniu konturów iluzyjnych. 
W tym momencie wyobraźnia bohatera wkracza w horyzont transcendentalny: „Chwila zatrzymania na wieczność, jak zatrzymało się biczujące ramię. [...] Patrzę spojrzeniem intensywnym i nie widzącym” [Karpiński 2002:133]. To oculis corporis i oculis mentis, odpowiednio: oczy ciała, zdolne postrzegać tylko świat zmysłowy, i oczy duszy, mogące ujrzeć to, co niewidzialne. Oko jest nie tylko „oknem na świat”, ale też „zwierciadłem duszy”. Okiem się widzi, lecz także wyraża się siebie. Jak podsumowuje bohater swoją podróż do Włoch, odwołując się do słów Muratowa:

Słowa: podróż do Włoch - są wiele mówiące, obejmują bowiem nasze doświadczenie, nasze życie we włoskim żywiole, wyzwolenie nowych sił duchowych, narodziny nowych zdolności, zwiększenie skali naszych pragnień. Dokonując się w czasie i przestrzeni, owa podróż prowadzi także przez głębie naszej istoty i zakreśla na dnie naszej duszy swój oślepiający krąg. [Karpiński 2002: 258]

Podróż do Włoch to dla bohatera bodziec wieloznaczny, a jego specyfika sprowadza się do dwóch wymiarów. Pierwszy polega na dostarczeniu odbiorcy kilku alternatyw percepcyjnych. Drugi to brak informacji zawartych w dziele, czyli dzieło w ruchu, projekt niedokończony. Zeki taką metodę odbioru określa jako non finito. Pobudza to wyobraźnię odbiorcy, jak również pozwala mu dokończyć dzieło w głowie, zgodnie $\mathrm{z}$ własnym pojęciem lub pojęciami mózgowymi. Umożliwia to wyzwolenie go z ograniczeń narzucanych tylko przez pojęcia istniejące w mózgu artysty. Relacja, którą nawiązuje odbiorca $z$ obrazem, to relacja podmiotowa, w której dochodzi do spotkania z Innym, z jego duchowością. Doświadczenie Drugiego łączy się z przeżywaniem piękna, poznaniem prawdy oraz obcowaniem z Absolutem. Funkcją dzieła sztuki jest uświadomienie człowiekowi prawdy o nim i o świecie zewnętrznym. Akt uzmysłowienia prawdy dokonuje się dzięki kontemplacji dzieła. W chwilowym doświadczeniu estetycznym stajemy się uczestnikami procesu, w którym piękno jest zmysłowym oświetleniem idei. Gdy doświadczamy tego światła, uświadamiamy sobie jakiś element prawdy duchowej dotyczącej natury świata, 
istoty człowieczeństwa lub wartości. Poprzez doznanie piękna człowiek odkrywa to, co najcenniejsze - niewidzialne bogactwo, które każdy człowiek posiada w swoim wnętrzu. Piękno to też obietnica czegoś więcej, pozwala uczestniczyć w samym źródle sensu bycia. Esto perpetua piękno świata i człowieka.

\section{Bibliografia}

Białostocki Jan (1966), Sztuka i myśl humanistyczna. Studia z dziejów i myśli o sztuce, PIW, Warszawa.

Bieńkowska Ewa (2009), Michał Anioł - nieszczęśliwy Rzymianin, Sic!, Warszawa.

Bull George (2002), Michat Aniot, przeł. Jan Paygert, pIw, Warszawa.

Chastel Andre (1978), Sztuka włoska, t. 2, przeł. Eligia Bąkowska, Wydawnictwa Artystyczne i Filmowe, Warszawa.

Condivi Ascanio (1960), Żywot Michała Anioła, przeł. Władysław Jabłonowski, pIw, Warszawa.

Duch Wodzisław (2003), Neurokognitywna teoria świadomości, w: Subiektywność a świadomość, red. Wioletta Dziarnowska, Andrzej Klawiter, Zysk i S-ka, Poznań, s. 133-154.

Karpiński Wojciech (2002), Pamięć Wtoch, Wydawnictwo słowo/obraz terytoria, Gdańsk.

Kawabata Hideaki, Zeki Semir (2004), Neural Correlates of Beauty, „J Neurophysiol”, nr 91, s. 1699-1705.

Kosslyn Stephen (2005), Mental Images and the Brain, „Cognitive Neuropsychology”, nr 22, s. 333-346.

Ligocki Alfred (1973), Sztuka renesansu, Wiedza Powszechna, Warszawa. Merleau-Ponty Maurice (1945), Phénoménologie de la perception, Librairie Gallimard, Paris [Francja], s. 16o-161.

Muratow Paweł (1988), Obrazy Wtoch, t. 1, przeł. Paweł Hertz, PIw, Warszawa.

Paivio Allan (1991), Images in Mind: The Evolution of a Theory, Harvester Wheatsheaf, New York [usA].

Przybysz Piotr (2006), O uchwytywaniu piękna. Rola deformacji estetycznych $w$ tworzeniu i percepcji dzieła sztuki $w$ ujęciu neuroestetyki, „Studia z Kognitywistyki i Filozofii Umysłu”, nr 2, s. 365-385.

Przybysz Piotr, Markiewicz Piotr (2006), Artysta jako nieświadomy neurobiolog, „Wiedza i Życie”, nr 2, s. 18-21.

Ramachandran Vilayanur Subramanian (2003), The Emerhing Mind, Profile Books, London [Wielka Brytania]. 
Ramachandran Vilayanur Subramanian, Hirstein William (1999),

The Science of Art. A Neurological Theory of Aesthetic Experience, "Journal of Consciousness Studies", nr 6-7, s. 15-51.

Tatarkiewicz Władysław (1967), Historia estetyki. Estetyka nowożytna, t. 3, Ossolineum, Wrocław.

Wallis Mieczysław (1975), Późna twórczość wielkich artystów, PIW,

Warszawa.

Zeki Semir (1999), Inner Vision. An Exploration of Art and the Brain, Oxford University Press, Oxford [Wielka Brytania].

Zeki Semir (2009), Blaski i cienie pracy mózgu. O miłości, sztuce i pogoni za szczęściem, przeł. Anna Binder, Marek Binder, Wydawnictwa Uniwersytetu Warszawskiego, Warszawa.

\section{Barbara Trygar}

\section{Memory of Italy by Wojciech Karpiński in the prospect of neuroaesthetic theory of Semira Zeki}

The aim of this article is to analyse Memory of Italy by Wojchech Karpinski in the in the prospect of the neuroaesthetic Semira Zeki theory. A works of art is an appropriately fabricated stimulus which is aimed at reprimanding the recipient. Evoking emotions at the spectator defined is included in nature of the works of art. The travel to Italy lets the hero experience the beauty, to find out the truth about world and about oneself, as well as to commune with the transcendental dimension.

Keywords: neuroaesthetic theory; Semir Zeki; works of art; emotions; beauty.

Barbara Trygar - doktor nauk humanistycznych, wykładowca w Instytucie Polonistyki i Dziennikarstwa Uniwersytetu Rzeszowskiego. W 2014 roku obroniła z wyróżnieniem rozprawę doktorską na Wydziale Filologicznym Uniwersytetu Rzeszowskiego. Jest współredaktorką (z Jolantą Pasterską) książki Przeżycie-Doświadczenie-Kontemplacja. Pisarstwo Kazimierza Brauna (Uniwersytet Rzeszowski, Rzeszów 2017), obecnie przygotowuje do publikacji książkę "Ja” $w$ drodze do Wolności, Prawdy i Piękna. Aspekty aksjologiczne twórczości prozatorskiej Kazimierza Brauna. Jej zainteresowania naukowe koncentrują się na zagadnieniach tożsamości i przestrzeni w literaturze emigracyjnej oraz migracyjnej, literaturze polskiej i obcej Xx oraz XXI wieku w perspektywie badań aksjologicznych, fenomenologicznych, kognitywi- 
stycznych, a także neuroestetycznych. Wśród osiągnięć i wyróżnień należy wymienić między innymi wyróżnienie i nagrodę przyznane przez Polskie Towarzystwo Filozoficzne w Warszawie, a także udział w III edycji Konkursu im. Inki Brodzkiej-Wald na najlepsze prace doktorskie, organizowanym przez Akademię Rozwoju Filantropii w Polsce. Jest członkiem Pracowni Badań i Dokumentacji Kultury Literackiej w Instytucie Polonistyki i Dziennikarstwa Uniwersytetu Rzeszowskiego. 